\title{
Study on Improving for Morality and Integrity Issues of Accounting Profession
}

\author{
Xin Cheng ${ }^{1, a}$, Yinxing $\mathrm{Li}^{1, \mathrm{~b}}$ \\ ${ }^{1}$ School of Economic Management, Beihua University, 132013, Jilin City, China. \\ aXi-cheng007@126.com; bnyjjgl@126.com
}

Keywords: Economy society, accounting profession, morality and integrity issues

\begin{abstract}
With the rapid development of the world economy, the professional accountant plays more important role in economy society. However, the account's morality and integrity has caused a series of problems for economic development. It is the people's attention to strengthen the integrity issues of accounting professionals to solution to related questions. In this paper, the gap between domestic and foreign was compared in order to find the solution methods. In the end, the Self-building and institutional constraints was proposed for improving the situation.
\end{abstract}

\section{Introduction}

In recent years, integrity and ethics in the accounting profession problem more and more serious, such as Anglo-American after another burst of Enron, WorldCom, and our "Yinguangxia" event so a series of scandals, the integrity of these crises on the one hand the impact the public image of the accounting staff, so the credibility of the accounting profession is compromised, but also caused widespread concern in the accounting profession people began to ethical issues.

After our government has played its functions under the rule of law and government affairs background, the Ministry of Finance and other relevant units began to increase efforts to check the quality of accounting information, preceded by three consecutive years of test results over the Commissioner's Office to make house announcement, in 2014 in the beginning, the first time the quality of accounting information of each inspection carried out by the provincial finance departments of the provincial announcement. In 2013, the Ministry of Finance organized a unified national financial ombudsman started many businesses across the country to carry out accounting supervision and inspection. Check the main focus of its central provisions of the eight anti-waste and the use of public funds. Checking out the many problems, mainly artificially manipulate profits, false accounting, revenue costs is not real, supervise implementation of internal control is not in place and other issues. At the same time, the Ministry of Finance is also on the part of insurance companies, securities companies and large state-owned commercial banks and other financial companies to check the quality of accounting information. Checked financial enterprises in the governance structure, financial management, internal control and other aspects of good performance, but some companies still exist some problems. Part of the enterprise internal control is weak, not strictly related to the implementation of financial and fiscal guidelines, there are some accounting issues Accounting false information, and some companies pay management and accounting irregularities, as well as the presence of a waste of resources, etc., some enterprises for credit risk assets classification is not accurate, according to the specified provision for reserve extraction.

Visible, morality is extremely important and essential part in the socialist economic construction, and is closely related to China's economic construction. Our accounting information distortion problem has been to jeopardize the normal operation of the socialist market economy, the quality of accounting information and therefore must get our attention. The reason, on the one hand, due to the socio-economic productivity is not high, inadequate legal construction, and related laws and regulations have been promulgated are not strictly enforced, and therefore cannot effectively restrain people all kinds of bad behavior; but on the other hand, its root cause analysis, it is due to the decline in moral standards of accounting personnel, some self-interest, ignoring the laws and regulations 
affecting the authenticity and accuracy of accounting information, which led to the occurrence of many false accounting reports.

It is in this socio-economic background, the choice of accounting industry credibility this problem by Review of the original document, combined with China's actual situation, The Status of the accounting professional ethics, problems and hazards, and then on through the status quo analysis of the causes, and finally put forward a sound accounting ethics measures, hoping to continue to improve and perfect the accounting professional ethics by these measures to improve the professional and ethical standards of accounting personnel, and lay a good foundation for the quality of accounting information.

\section{Moral consciousness system}

Morality as an ideology, has experienced from a bud to mature, all the long history of the development process from a few people realize that most people clear consciousness, in different historical period of development, with different moral meaning, content, character and specific functions. Ethics is a branch of moral refinement, and accounting professional ethics is part of professional ethics, which refers to the accounting industry, employing a series of actions by accounting activities caused by its moral and closely related. Resulting from these acts out of a series of moral theory. And compliance with accounting professional ethics, as required act, act in accordance with laws and regulations, the law as the criterion, should be a basic requirement of every accounting practitioners when entering the accounting profession, the need to constantly remind ourselves.

First, the moral is the proper measure of a person's behavior in the eyes of the secular or not a standard. These standards are right or wrong in a production level of development and the relations of production change naturally formed. Second, morality is a social ideology, according to people living together and act evolved a series of standards and norms, has great similarities. Morality is determined by certain economic basis of society, and to a certain social and economic infrastructure and services, is a process system, with the changing times, the moral values of different classes are constantly changing.

The word "moral", first appeared in Chinese, can be traced back to the pre-Qin thinkers Laozi book "Dao De Jing", a book. He said: "Dawson, the German animal, the shape of the object, based on all of the potential into the road and respect for everyone in Guide." The "Road" means the operation of the natural and the human world of simple common sense; and "virtue" It refers to a person's character and quality. The "moral" word begins $\mathrm{Zi}$ "Encouraging Learning" chapter: "So learn to carry almost full length ceremony, the husband is the moral of that extreme." Since then, the "moral" meaning of the word combination together. Fan Ye, "Han • Species Dai Biography" also spoke: "I heard that the moral virtue Xing Chang, Chang is the political morality of the Ming and government of the Ming and Wan Ning name" can be seen with a moral country regime is closely related to the development, it is very important. One feature is its morality is universal, for all society as a whole, regardless of the identity, are applicable ethical standards, it can be said is that everyone is equal before the moral, no one is special, it is beyond of morality. "University" in: "from the emperor as well as common people, first begin with self-centered." Therefore, "moral" human views on the world, and no matter what the identity of the person, are treated equally in the moral standard is the same? And a person must constantly cultivate their moral standards, to improve their moral cultivation, no matter who you are, we must follow the constraints moral system.

First, ethics refers to personnel engaged in accounting should comply with one kind of ethics prevailing in the industry. In the process employed, the improper practices should not be used to serve their own interests, not the interests of acceptance should not be accepted, the work cannot leak privacy, not because the employer or supervisor of pressure, and in some of its proposed accounting violation professional ethics, breach of laws and regulations, regardless of the legal yardstick to make unethical behavior. 
Engels once said: "In fact, every class, even every profession, has its own ethics." Ethics is the practice of life and work practices from the people gradually produced, each industry has its own characteristics. From a historical perspective, ethics sprout starts at the end of the primitive society, and later occupation handicrafts, agriculture, animal husbandry and other division of labor gradually began to appear. After entering the class society, with the continuous development of productive forces, the demand of the industry, and slowly subdivided into more industries. These are broken down for specific career practitioners have put forward higher requirements. They not only want people to have specific knowledge and skills to the task, and requires a person in the industry to have the professional ethics of the industry evolving in order to better maintain order more professional industry. A variety of industry practitioners, in order to meet the needs of society and effectively safeguard the interests of the industry and reputation, through the accumulation of practice, gradually formed the industry-specific code of ethics. In ancient China, it has been recorded in this regard. For example, China's ancient art of war, "The Art of War", in relation mentioned about "who will, wisdom and trust, benevolence, courage and strict also" records. This is relatively early in the definition of professional ethics, it has far-reaching significance.

Thus, ethics is under the influence of economic development and occupational health division of the society changing, the former is the basis of the latter, the latter plays the role of a constraint. At this time the development of ethics and did not form a system, but merely only from certain industrial and commercial guild regulations or famous people engaged in the industry to find the words and deeds and writings contain something about ethics, and not enough complete and mature. The period of capitalist development of commodity economy, the rapid development of productive forces, thus contributing to the further deepening social division of labor, occupation and industry are increasing, subdivision, complex. In different sectors of occupation groups, in order to enhance their competitiveness and improve their professional reputation, improve work efficiency and staff level, so have to promote ethics and some even set up professional associations and to develop the Articles of Association, the provisions of occupational purpose and career ethics, the initial formation of the accounting professional ethics system. And through continuous development, and proven to complement them, and ultimately the formation of a mature industry ethics system, to facilitate and promote the popularization and development of professional ethics. They first before existing medical ethics, the ethics, morality, professional ethics and other German officials further enriched and improved, but there is a lot more detailed branches, making ethical system more perfect. However, many ethical systems are very much restricted in the specific practice of capitalist society, and cannot execute down as expected. So has characterized the hypocrisy of many sectors of professional ethics, only superficial, and cannot realistically be practiced according to the practice of it, when you need to promote it, but when you do not need to ignore it.

\section{Accounting professional ethics content}

Accounting professional ethics of the latest laws and regulations promulgated, mainly to the moral standards of accounting practitioners made specific provisions, hoping constraints and norms of accounting personnel, its main contents include: "dedication, honesty and trustworthiness, self-discipline, objectivity, guidelines, skills, participation in management and enhance service, "the eight. And these points can be summarized as follows:

Honesty is a person to walk the talk, honest man, realistically do their work. The word refers to a person can do, credible commitment to their own promise can practice out on the action, not when it comes to do. The fair is to require countries to uniform accounting system, effective implementation and monitoring of accounting standards, accounting system, improve accounting profession system, just carry out accounting and accounting supervision, so that the accounting work can be more transparent. CPA should be a fair and equitable manner the audit work, audit work carried out in strict accordance with the requirements of laws and regulations, and ultimately be able to produce objective and appropriate audit opinions, do not give false accounting information to an opportunity. 
Objectivity and impartiality complement each other, the former is the basis of the latter, which is a reflection of the former. The basic requirements are the following:

1) Accounting personnel should strictly abide by its word, act in good faith, seek truth from facts do their job, to be careful accounting of accounting, minimize and avoid all kinds of artificial mistakes. At the same time we want to resist the temptation of interest, not for personal gain, cooking the books, harm the public interest.

2) Do security work? Accounting officer for access to the unit and the customer's confidential should be kept confidential, cannot disclose to others, should do honest and trustworthy, act in accordance with rules and regulations.

3) Practicing cautious. Accounting practitioners should always exercise due caution, as they relate to accounting and money more closely, and should therefore work to do due diligence, depending on the professional reputation first. In practice customers should choose carefully, refusing to meet customer unfair requirements, guidelines and practice norms and accounting personnel during the operation should be strictly in accordance with the accounting-related industries.

4) To correct attitude. Accountants employed in the process should be strictly in accordance with the laws and regulations of work, and have a good working attitude and knowledge and skills. Work should be done in accordance with the law, strictly abide by professional ethics, not to cook the books, cautious work, and is responsible for the final result.

Self-discipline requires the accounting officer can consciously resist their bad desires, at work, refusing the temptation to be firmly resisted. Guidelines refers to accounting personnel should strictly abide by the provisions of the legal system of accounting services, and not by the influence of superiors or leadership will make things contrary to the accounting profession ethics. When practitioners of moral conflict process, the guidelines should be first, always bear in mind the legal yardstick, according to the law, do not do illegal things. When the CPA audit services, should be strictly in accordance with the independent auditing standards, step by step carefully audited to the audited company, and finally to the audited company should be fair and objective audit reports to ensure the authenticity of the contents of the audit. The basic requirements include the following:

Accounting personnel shall take action in self-discipline in the first place, not consciously resist today's socialist economic life, socialist ethics plays an important role, not only to adapt to socialist material civilization and spiritual civilization It needs, but under the guidance of the communist moral principles selectively inherited the contents of the history of outstanding professional ethics system, and combined with the actual situation in China, the traditional basis to continue to grow and develop, formed Chinese characteristics accounting profession system. China has developed a variety of walks of life stage on occupational conventions of the industry, such as the People's Liberation Army "military oath", factories and enterprises, "Staff Regulations" and so on, the provisions of this industry, the socialist ethical content the reaction of the constraint industry personnel has a very important role, which has a great influence in all walks of professional life.

The accounting professional ethics in this article focuses on, which means mainly refers to all activities in the accounting profession should follow and reflect the economic relations between the accounting profession, the characteristics of the accounting profession, as well as the relationship between the accounting profession and professional code of conduct. A concrete manifestation of the accounting professional ethics, and the reaction in the daily accounting work, for example guidance and constraints accounting practices and social norms have to adjust the relationship between standards and accounting personnel between accounting personnel with a variety of interest groups as well as between the accountants Wait. China has developed a variety of walks of life stage on occupational conventions of the industry, such as the People's Liberation Army "military oath", factories and enterprises, "Staff Regulations" and so on, the provisions of this industry, the socialist ethical content the reaction of the constraint industry personnel has a very important role, which has a great influence in all walks of professional life. It exists in all areas of accounting and the whole process, reflecting the mutual unified social needs and personal development, focusing on the evaluation of the relationship is reasonable, as well as substandard adjustment standards, social 
evaluation and personal evaluation is one of the major constraints, It is a non-mandatory normative work.

\section{Measures to improve accounting professional ethics}

From the above analysis can be seen, China's accounting professional ethics have been some achievements, accounting professional ethics system has an initial prototype, but there are many places is not mature enough, there are still many problems. Compared with developed countries, China's accounting professional ethics system is still a certain gap, there are many way to go. So you want to be serious attention to the moral aspects of problems in the field of accounting profession and the accounting profession viewed from different angles of the problem, change the status of the accounting profession, to improve the quality and level of the day accounting industry personnel, clean environment accounting industry practitioners .

Carry out accounting professional ethics education is an essential tool, its main purpose is to hope that through the accounting professional ethics training and indoctrination, so that the accounting professional ethics into the accounting staff within specification can own ideas and experiences with their own moral qualities and integration, and ultimately can be achieved naturally guidance and constraints of their own behavior, compliance with accounting integrity, improve the moral level accounting personnel.

Accounting officer should consciously take the initiative to learn the content accounting professional ethics, strengthen its accounting professional construction, because of personal ideological and moral standards and political consciousness related to the specific behaviors themselves manifested in the work, attitude and work ethic in the past. This will largely depend on the accounting of employees own efforts to strengthen their own moral construction, with moral strength regulate their own behavior, act according to the laws and regulations in their work to ensure fair economic activity. Meanwhile, the accountant must have a strong sense of learning, and has a higher ability to analyze problems. They should continue to accept the follow-up education, continue to strengthen the business of learning, maintained pace with changes in economic trends and the accounting system and the tax system. Only proficiency standards and legal requirements, and continuously improve their professional judgment ability, in order to better carry out the accounting work.

Accounting ethics education should permeate education accountants always, continue to strengthen the accounting professional ethics of accounting personnel, accounting personnel to enhance the moral level, should be a lifelong goal of every accounting staff. Accounting professional ethics education targets should be primarily aimed at students in the accounting profession, ready to engage in accounting work and accounting staff accounting positions are working. In spirit, the main requirements of accounting personnel can act according to the law, integrity, realistic, time law as the criterion; for accounting staff service attitude, the main requirements of accounting personnel to correct the attitude of serving the people, to establish the spirit of serving the people, to practice adhere to serve the people of faith; compliance with law abiding education, strengthening legal education policy accounting personnel, accounting standards can stick to, things do break the law.

\section{Summary}

In this paper made a number of practical policies. First, it should correct the accounting officer thinking, strengthen the accounting professional ethics education, importance of accounting ethics education and training, allowed consciously their behavior closer to accounting standards, which step by step train accounting staff professionalism; Secondly, macro, should pay more attention to the construction of the accounting professional ethics of the environment, the government should strengthen the accounting industry practitioners environment, and take effective ways to make practitioners to purify the environment, helping accountants better jobs; Third, to further improve the accounting system building, establish and improve accounting personnel and accounting firm credit 
file, the summary information together so you can more efficiently managed; and finally, improve the internal mechanism of enterprises, solve the problem from within the enterprise, to further strengthen the supervision of the policies and regulations continue to implement.

Chinese scholars' lack of professional ethics for the accounting problems has made some achievements, the initial formation of a theoretical system for China's accounting industry to make a contribution. To really solve the problem of lack of accounting ethics, and people need the government to make all aspects of our action in the theory and practice, rather than merely on theoretical analysis, we need to practice to verify the theory is correct or not. Due to my limited knowledge and conditions, there are still many problems in the paper, the study of some issues is not deep enough, set forth the view is not mature enough, willing to please we can give criticism.

Corresponding Author: China.

Professor Yinxing Li, School of Economic Management, Beihua University, 132013, Jilin City,

\section{References}

1. Eric Pan. Eric Pan corpus. Shanghai: Lixin Accounting Press, 2008.

2. Mawei Juan, Zhao Zhongwei. Discussion on Accounting Professional Ethics. Accounting Research, 2013 (3).

3. Pei. New Period Accounting Professional Moral Standard and Reconstruction. Economic perspective, 2013 (8).

4. Zhao Yan. On the way to enhance accounting professional ethics. New West, 2014 (36).

5. Yang Ming months. Discipline and law: Situation and Construction of Accountants' Professional Ethics. Business Economics, 2014 (10).

6. Fujia Heng. Talking about the accounting professional ethics. Economic and technological cooperation, 2014 (9).

7. Simply extraordinary. Research on the issue of integrity in accounting ethics. Market Modernization, 2015 (1).

8. Jian-Hui Lin. Explore the social role of financial regulations and accounting professional ethics. Chinese e-commerce, 2015 (1).

9. Tao Yun three Jiayi Zheng Multimedia Educational Technology in College Sports Teaching Problems and Countermeasures of Anhui Technical Teachers College, 19 (2005). 